\title{
Amalan Kesantunan Berbahasa dalam Komunikasi Formal dan Tidak Formal dalam Kalangan Pelajar Universiti
}

\author{
AHMAD FUAD MAT HASSAN \\ KHAIRUL FAIZ ALIMI \\ HISHAMUDIN ISAM \\ MASHETOH ABD MUTALIB \\ Universiti Utara Malaysia
}

\begin{abstract}
ABSTRAK
Kesantunan berbahasa ketika berkomunikasi amat dititikberatkan oleh masyarakat di Malaysia khususnya orang Melayu. Amalan kesantunan berbahasa adalah perkara asas dalam sesebuah komunikasi yang menggambarkan aturan sosial dalam sesebuah masyarakat dan menjadi prasyarat bagi kerjasama dalam sesebuah komunikasi. Kajian ini bertujuan untuk mengenal pasti amalan kesantunan berbahasa yang diamalkan oleh pelajar UUM dalam konteks komunikasi formal dan tidak formal, membandingkan elemen kesantunan berbahasa yang diamalkan oleh pelajar mengikut jantina dan membincangkan kesan terhadap amalan kesantunan berbahasa dalam komunikasi kepada pelajar. Sebanyak 1251 orang responden dipilih dan ditemu bual menggunakan borang soal selidik berstruktur yang dibina berdasarkan konteks formal dan tidak formal. Kajian ini mengaplikasikan teori kesantunan Brown dan Levinson (1987) sebagai landasan dalam membincangkan dapatan kajian. Hasil kajian mendapati, sebanyak 93.2 peratus (1166) orang pelajar UUM mengamalkan kesantunan berbahasa dalam konteks formal dan selebihnya sebanyak 6.8 peratus (85) orang responden sahaja yang kurang menitikberatkan elemen kesantunan berbahasa ketika berkomunikasi dalam konteks formal. Dari segi jantina pula, dapatan kajian menunjukkan bahawa terdapat perbezaan yang signifikan terhadap amalan kesantunan berbahasa antara pelajar lelaki dan perempuan, iaitu $\mathrm{t}(1249)=3.652, \mathrm{p}<.05$. Hal ini menunjukkan bahawa pelajar perempuan lebih mengamalkan kesantunan berbahasa ketika berkomunikasi berbanding dengan pelajar lelaki. Selain itu, amalan kesantunan berbahasa dalam komunikasi pelajar telah memberikan kesan yang positif kepada pelajar khususnya di UUM. Amalan kesantunan berbahasa perlu dilestarikan oleh setiap individu kerana amalan ini bukan sahaja dituntut dalam beragama malah ianya dapat menggambarkan nilai budi leluhur sesuatu bangsa dalam konteks di Malaysia.
\end{abstract}

Kata kunci: Kesantunan berbahasa, komunikasi formal, komunikasi tidak formal, pelajar universiti, bangsa.

\section{The Practice of Language Politeness in Formal and Informal Communication Among University Students}

\footnotetext{
ABSTRACT

The practice of language politeness in communication is deemed significant by Malaysians, particularly the Malays. Language politeness is centre in communication, as it exemplifies social structure and serves as a prerequisite to social cooperation. This study aims to identify the practice of language politeness 
among the UUM students in both formal and informal contexts, evaluate the depiction of language politeness elements by the students based on gender and deliberate the effects of the practice of language politeness in communication for the students. A total of 1251 respondents were selected and interviewed using a structured questionnaire encompassing formal and informal contexts. Brown and Levinson's theory of politeness (1987) opted for the study to benchmark the research findings. The findings reveal 93.2 per cent (1166) of the UUM students exercised language politeness in the formal context, whilst the remaining 6.8 per cent (85) placed less emphasis on language politeness in the same context. The findings on gender indicate a significant difference between the practice of language politeness of the male and female students, i.e. $t(1249)=3.652, p<.05$. This tells that more female students exercised language politeness in communication than their male counterparts. The study also found that the practice of language politeness in communication among students has positively benefitted the students themselves, especially at UUM. This practise needs to be sustained by each individual, as it is not only demanded by religion but can also reflect the ancestral values and virtues of a nation such as Malaysia.

Keywords: Practice of language politeness, formal context, informal context, university students, nation.

\section{PENGENALAN}

Kesantunan berbahasa merujuk kepada penggunaan bahasa yang tertib dan halus, bahasa yang mempunyai nilai hormat kepada seseorang, mempunyai unsur keteguhan dan persetujuan, mempunyai nilai kerendahan hati, kesetiaan dan berintegriti ketika berkomunikasi. Dalam menjelaskan hal ini, Lakoff (1975) dan Lakoff dan Bucholtz (2004) mengatakan bahawa prinsip kesantunan itu dibangunkan oleh sesebuah masyarakat dalam usaha untuk mengurangkan pergeseran dalam interaksi peribadi, sekali gus dapat dijadikan strategi untuk mengelakkan konflik (Leech, 1983). Aspek kesopanan wajar diamalkan mengikut parameter kesantunan dalam pragmatik (Zaitul, 2009; Kalthum \& Nur Faezah, 2017). Oleh yang demikian, amalan kesantunan berbahasa merujuk kepada “...berbudi bahasa adalah percakapan dan komunikasi yang baik, elok dalam tutur kata, halus tutur kata, hormat, bijaksana, tinggi budi bicara, pemurah, belas kasihan, beradab, bersopan santun, bertatatertib, berbudi pekerti mulia, tingkah laku yang baik, dan akhlak yang baik dalam diri setiap individu dan masyarakat..." (Mustafa, 1995).

Kesantunan berbahasa ketika berkomunikasi dalam kalangan masyarakat di Malaysia bukanlah isu baharu, malah amalan ini kian sirna lebih-lebih lagi dalam kalangan remaja. Dalam menjelaskan hal ini, Mantan Menteri Penerangan Komunikasi dan Kebudayaan, Dato' Sri Utama Dr. Rais Yatim (Utusan Malaysia, 1 Julai 2011) mengatakan bahawa generasi muda berdepan dengan isu tahap kesantunan yang semakin membimbangkan. Pendapat ini turut disuarakan oleh Senator Dato' Dr. Firdaus Abdullah, (Utusan Malaysia, 7 Julai 2011) dalam Sidang Dewan Negara yang mengatakan bahawa penggunaan bahasa oleh golongan muda merosot nilai kesantunannya kerana segelintir daripada mereka tidak segan silu bertindak biadap ketika berkomunikasi. Keadaan ini secara tidak langsung menggambarkan bahawa, etika santun berbahasa dalam komunikasi generasi muda atau remaja di Malaysia kini sangat membimbangkan. Walaupun sekadar pandangan umum tanpa kajian yang terperinci, namun hal ini wajar diperhalusi secara empirikal dan saintifik. Oleh yang demikian, secara khususnya kajian ini dijalankan untuk mengenal pasti amalan kesantunan berbahasa yang diamalkan oleh remaja dengan berfokus 
kepada pelajar di institusi pengajian tinggi (IPT). Dapatan kajian ini sekurang-kurangnya dapat memberikan gambaran mengenai amalan kesantunan sekelompok remaja yang berfokus kepada pelajar institusi pengajian tinggi di Malaysia.

\section{AMALAN KESANTUNAN}

Amalan kesantunan ialah suatu amalan yang ada nilai santunnya seperti penggunaan bahasa, pemilihan leksikal, nada dan intonasi dalam ujaran. Dalam aspek perilaku, kesantunan juga tergambar melalui tindak-tanduk yang tidak melangkaui norma budaya sesuatu bangsa dan masyarakat. Menurut Zuraini, Husna, Dahlia dan Khairul Azam (2009), amalan kesantunan dalam berbahasa terangkum dalam budaya santun dalam masyarakat. Hal ini diperkukuh oleh Asmah (2003) yang menyatakan bahawa elemen bahasa dan budaya harus dilihat secara bersama tanpa pengasingan kerana gabungan kedua-duanya mampu membentuk indeks peradaban sesebuah bangsa.

Dalam kajian ini, amalan kesantunan berbahasa pelajar IPT yang dikaji akan diukur dalam konteks formal dan tidak formal berdasarkan pandangan Asmah (2015). Menurut beliau bahasa formal ialah bahasa yang digunakan dalam situasi rasmi seperti dalam upacara rasmi, dalam pengurusan dan pentadbiran, dan dalam pengajaran di sekolah, universiti dan institusi-institusi pendidikan yang lain, serta juga dalam media massa. Manakala bahasa tidak formal atau disebut juga sebagai bahasa basahan merupakan bahasa yang digunakan dalam perbualan sehari-hari dan tidak digunakan dalam tulisan. Kedua-dua konteks ini wajar diukur secara bersama bagi memperlihat situasi sebenar amalan kesantunan berbahasa seseorang. Pengukuran amalan kesantunan ini pula seharusnya dikaitkan dengan teori yang sesuai untuk memantapkan dapatan kajian hasil daripada analisis yang dijalankan. Sebelum hal ini dibincangkan secara panjang lebar dalam kaedah kajian, maka sewajarnya diteliti terlebih dahulu kajian-kajian lepas yang telah membincangkan isu berkaitan amalan kesantunan dan kesantunan berbahasa.

\section{SOROTAN KARYA}

Kajian mengenai amalan kesantunan dan kesantunan berbahasa dalam komunikasi manusia telah mendapat tempat dalam kalangan pengkaji bahasa. Di Malaysia, misalnya terdapat beberapa kajian yang meneliti elemen kesantunan yang digunakan oleh masyarakat setempat. Marlyna (2011) antaranya, mengkaji elemen kesantunan yang digunakan oleh masyarakat Melayu ketika membuat teguran. Kajian tersebut melibatkan 24 penutur asli bahasa Melayu dan membentuk 12 pasangan akrab yang terlibat secara langsung dengan lakuan bahasa teguran. Semua penutur dalam kajian ini adalah golongan profesional muda, berpendidikan tinggi, dan menetap di bandar besar. Berdasarkan Teori Kesantunan (Brown \& Levinson, 1978; 1987), kajian mendapati bahawa informan kajian masih mengekalkan elemen kesantunan dalam membuat teguran. Hasil kajian mendapati bahawa penutur mengurangkan ancaman terhadap air muka dalam komunikasi mereka melalui strategi kesantunan negatif melalui beberapa pernyataan lindungan, bayangan, dan penghentian yang agak lama di tengah-tengah giliran ujaran. Dapatan yang diperoleh juga menunjukkan bahawa komuniti yang menggunakan bahasa Melayu masih 
berpegang kepada nilai budaya Melayu dan menjaga air muka dalam komunikasi antara peribadi, walaupun mereka dalam golongan berpendidikan tinggi, berdaya saing, menyahut tuntutan modenisasi dan urbanisasi. Semua 24 orang profesional muda yang mewakili komuniti bahasa ini masih mengekalkan nilai budaya berbahasa mereka.

Dalam adat pepatih, kajian Norhana, Zaitul, Hamzah, dan Abd Rani (2010) mendapati bahawa elemen kesantunan bahasa dipaparkan melalui penggunaan kata perbilangan adat. Hal ini demikian kerana, dalam kehidupan seharian ada kalanya tidak semua pengungkapan bahasa kelihatan sopan apabila diujarkan secara terus terang dalam keadaan yang terbuka, lebih-lebih lagi hal yang berkaitan dengan peraturan yang perlu dipatuhi dalam kehidupan bermasyarakat. Menurut Norhana et.al (2010), kata perbilangan adat mempunyai unsur-unsur santun seperti penggunaan Maksim Santun/Berhemah, penggunaan Maksim Budiman/Kedermawan dan penggunaan Maksim Sokongan/Sanjungan. Maksim santun atau berhemah "digunakan dalam cara dan teknik seseorang itu ketika menjalankan sesuatu perundingan atau perbicaraan, khususnya dalam perbincangan beradat". Maksim Budiman/Kedermawan "tergambar dalam hubungan yang erat antara satu sama lain dalam kehidupan hariannya seperti sesuatu pekerjaan dilakukan bersama-sama dan setiap anggota masyarakat berhak untuk mendapatkan faedah yang sama walaupun kadar bilangannya agak terhad". Maksim Sokongan/Sanjungan "terdapat dalam ungkapan yang menyatakan setiap anggota adat mempunyai tugas-tugas yang tersendiri". Justeru dalam masyarakat adat Perpatih, kata perbilangan adat dijadikan landasan ujaran sopan secara khususnya untuk membuat penegasan dan ada kalanya mungkin akan menyinggung perasaan orang lain.

Program rancangan bual bicara radio yang berbentuk panggilan masuk turut menitikberatkan elemen kesantunan ketika dalam komunikasi dua hala. Rancangan bual bicara radio yang dikaji oleh Arina Johari dan Indirawati (2016) merupakan rancangan yang melibatkan pemanggil telefon dan tetamu undangan di konti radio sebagai pemberi nasihat. Analisis menggunakan Model Pola Kombinasi Strategi dan Maksim (MPKSM) mendapati bahawa wujud kesantunan positif yang terdapat dalam lakuan menjawab salam, berterima kasih, memuji dan memperlihatkan persetujuan secara langsung. Perlakuan tersebut dapat memupuk hubungan silaturahim, kasih sayang, dan mencerminkan sikap rendah diri seseorang. Strategi kesantunan negatif pula terdapat dalam perlakuan menegur dan memberi arahan yang ditujukan kepada pemanggil atau pendengar secara berlapik. Hal berkenaan menunjukkan kesedaran peserta perbualan untuk mewujudkan suasana harmoni sepanjang komunikasi berlangsung.

Selain itu, elemen kesantunan merupakan elemen yang penting dalam perhubungan pelbagai etnik terutama dalam perhubungan antara murid. Kajian strategi komunikasi dalam kalangan murid pelbagai etnik telah dijalankan oleh Zulkifley, Naidatul dan Asyraf (2015), mendapati bahawa "...murid-murid Melayu menggunakan pelbagai kata ganti nama diri semasa berkomunikasi. Kata ganti nama 'aku - kau' dan 'saya - awak' paling kerap digunakan oleh murid Melayu berbanding murid bukan Melayu semasa berkomunikasi. Murid bukan Melayu pula lebih selesa menggunakan 'saya - kamu' dalam proses komunikasi...". Hasilnya, kegagalan pelajar menggunakan kata ganti nama yang tepat boleh menggugat keharmonian dalam hubungan antara etnik. Pembelajaran kata ganti nama perlu juga diberi perhatian dalam konteks fungsi dan 
makna kata ganti nama tersebut sebagai ujaran santun ketika berkomunikasi mengikut pangkat umur dan status pekerjaan yang bersesuaian.

Kesantunan dan pemilihan kata ganti nama turut dikaji dalam kalangan pelatih PLKN. Kajian berkenaan dilakukan oleh Nor Azuwan, Norazlina, Kamariah, dan Zaitul (2011) yang melibatkan seramai 400 orang pelatih yang terdiri daripada pelbagai latar belakang etnik. Kajian yang dilakukan tidak hanya tertumpu dalam aspek ganti nama sahaja berikutan elemen seperti pemilihan ungkapan turut dimasukkan sebagai item yang diuji. Hasil analisis statistik mendapati bahawa “...tahap kesantunan berbahasa pelatih PLKN berada pada tahap yang tinggi dengan purata peratus melebihi $90 \%$. Keadaan ini menunjukkan tahap kesantunan berbahasa dalam kalangan pelatih dapat dibanggakan. Konsep kesantunan berbahasa memainkan peranan penting dalam membudayakan pelatih dengan imej kesantunan ketika berkomunikasi dan ianya dapat mencerminkan nilai yang bersih serta membawa mereka kepada tahap peribadi yang berkualiti dan cemerlang pada masa hadapan".

Dalam konteks sosiobudaya, Ibrahim (2019) telah menjalankan kajian yang melihat konteks budaya dalam komunikasi antara budaya (kes Pelajar IAIN Pontianak, Indonesia). Kajian ini meneliti kecenderungan pelajar di IAIN Pontianak berkomunikasi konteks tinggi (HCC), bukan konteks rendah (LCC) dalam aspek aspek sikap dan gaya komunikasi pelajar dalam konteks pertemanan, persahabatan, dan hubungan sosial. Dapatan kajian menunjukkan bahawa “....wujudnya ketiga-tiga konteks budaya tersebut dalam komunikasi pelajar, dengan kecenderungan LCC yang lebih dominan dalam sikap, dan HCC dalam gaya komunikasi. Dalam konteks pertemanan; kecenderungan utama sikap komunikasi pelajar adalah budaya campuran LCC dan HCC, seterusnya HCC, dan LCC. Gaya komunikasi pelajar pula lebih cenderung kepada LCC, seterusnya campuran LCC dan HCC, dan HCC. Dalam konteks persahabatan; kecenderungan utama sikap komunikasi pelajar adalah LCC, kemudian HCC dan campuran LCC dan HCC. Dalam gaya komunikasi pelajar lebih cenderung kepada HCC, seterusnya LCC dan campuran LCC dan HCC. Dalam konteks hubungan sosial; kecenderungan utama komunikasi pelajar adalah LCC, campuran LCC dan HCC, dan HCC...." baik dari aspek sikap mahupun gaya komunikasi mereka. Dapatan-dapatan kajian kesantunan dalam konteks pendidikan (Zulkifley Hamid dan Naidatul Zamrizam Abu dan Ashraf Zulkifley 2015; Nor Azuwan Yaakob et.al, 2011; dan Ibrahim 2019) sekurang-kurangnya memberikan gambaran amalan dan lakuan santun dalam mendidik anak bangsa dan dalam komunikasi. Hal ini bagi menjaga dan mengekalkan ciri-ciri masyarakat timur yang penuh dengan budaya ketimuran untuk diperturunkan kepada generasi seterusnya.

Kepesatan perkembangan teknologi media khususnya media sosial pada hari ini telah menarik minat pengkaji untuk menjalankan kajian yang memfokuskan amalan kesantunan dalam konteks media sosial. Antaranya Sa'adiah (2015) yang menjalankan kajian tentang pemilihan bahasa dalam komunikasi di laman sosial dan Maslida (2018) yang melihat trend ganti nama diri bahasa melayu dalam konteks media sosial. Kajian Sa'adiah (2015) meninjau pemilihan bahasa dalam komunikasi pengguna laman sosial yang diakses melalui capaian internet. Hasil kajiannya menunjukkan “....bahawa bahasa Melayu dan bahasa Inggeris menjadi pilihan pengguna laman sosial diikuti oleh bahasa Cina, bahasa India, dan bahasa-bahasa lain. Selain itu, dapatan kajian 
menunjukkan bahawa pola pemilihan bahasa yang digunakan di laman sosial adalah sama bagi tujuan komunikasi yang berlainan, iaitu bahasa".

Kajian Maslida (2018), telah meneliti trend penggunaan kata ganti nama diri dalam kalangan pengguna media sosial dalam konteks komunikasi yang melibatkan rakan sebaya dan berlaku dalam situasi tidak formal. Beliau menggunakan aplikasi WhatsApp dalam telefon pintar sebagai data kajian. Hasil kajiannya mendapati bahawa "....terdapat empat bentuk kata ganti nama diri digunakan dalam perbualan pengguna WhatsApp, iaitu kata ganti nama diri pertama (penutur), kata ganti nama diri kedua (pendengar), kata ganti nama diri ketiga (sasaran) dan kata ganti nama diri kosong. Kajian juga mendapati tiga bentuk kata ganti diri yang menjadi trend dalam aplikasi WhatsApp, iaitu kata ganti nama diri singkatan, kata ganti nama diri dialek dan kata ganti nama diri kontemporari".

Amalan kesantunan berbahasa dalam komunikasi seharian amat dititikberatkan dalam agama Islam. Nur Damia Husna dan Zulkefli (2015) membincangkan etika komunikasi menurut Islam daripada beberapa surah al-quran, iaitu “....Qaulan Sadida (QS.4 an-Nisa': 9), iaitu medium bahasa yang digunakan mestilah jujur dan benar pengisiannya. Qaulan Ma'rufa (QS.4 an-Nisa': 8) yang menyarankan agar manusia dapat berkomunikasi dengan bahasa yang baik dan tidak menyentuh jiwa atau perasaan khalayak. Qaulan Baligha (QS.4 al-Nisa': 63) pula menekankan maklumat yang disebarkan kepada masyarakat hendaklah mampu meninggalkan kesan kepada jiwa mereka. Qaulan Maisura (QS.17: al-Isra': 28) memperingatkan para pendakwah bahawa maklumat yang disebarkan mestilah mampu difahami sesuai dengan tahap kemampuan para pendengar. Ayat Qaulan Karima (QS.17: al-Isra': 23) menjelaskan bahawa bahasa dan perkataan yang diungkapkan mestilah mempunyai nilai yang baik dan mulia. Etika komunikasi menurut Islam menggambarkan peri pentingnya kesantunan dalam metodologi dakwah sebagaimana yang terdapat dalam surah al-Nahl ayat 125 merupakan satu gambaran tentang kesantunan dalam berkomunikasi yang meliputi unsur-unsur seperti al-hikmah, al-maw'izah al-hasanah dan al-mujadalah bi al-husna".

Hasil analisis kritis terhadap sorotan kajian lepas mendapati bahawa perbincangan terhadap kesantunan berbahasa dan amalan kesantunan tidak memperlihat kajian yang berfokus dalam meneliti aspek kesantunan berbahasa dalam konteks formal dan tidak formal. Bertitik tolak daripada isu tersebut, penyelidikan ini akan memfokuskan kepada aspek kesantunan berbahasa dalam konteks formal dan tidak formal dengan menjadikan remaja yang menuntut di IPT sebagai responden kajian.

\section{METODOLOGI}

Kajian ini menerapkan kaedah tinjauan berbentuk keratan rentas (cross sectional) oleh Creswell (2008). Menerusi kaedah ini, kajian deskriptif yang dijalankan sesuai untuk menguji sikap, kepercayaan dan tingkah laku individu. Oleh itu, aspek penting yang perlu ditekankan ialah pemilihan responden yang dapat mewakili keperluan kajian bagi menggambarkan sikap, kepercayaan dan tingkah laku individu yang dikaji. Bagi merealisasikan hasrat tersebut, responden yang dipilih untuk mewakili amalan kesantunan dalam kalangan remaja di Malaysia ialah pelajar IPT yang menuntut di Universiti Utara Malaysia (UUM). Seramai 1251 orang pelajar 
UUM telah dipilih secara rawak yang mewakili kepelbagaian sosio, ekonomi dan status (SES) serta latar belakang pengajian yang berbeza. Daripada jumlah tersebut, seramai 382 orang responden mewakili remaja lelaki dan 869 orang responden mewakili remaja perempuan.

Data kajian dikumpul dengan menggunakan borang soal selidik yang dibina secara berstruktur. Sebanyak sepuluh item soal selidik dibina berkaitan dengan konteks formal dan tidak formal. Soalan yang berkaitan dengan konteks formal dirangka dengan mengambil kira situasi ketika pelajar berkomunikasi dengan pensyarah di kelas dan ketika pelajar berurusan dengan pegawai di kaunter/pejabat. Manakala konteks soalan yang tidak formal pula dirangka berkaitan dengan situasi pelajar berkomunikasi dengan pelajar lain dan ketika pelajar menyertai program pusat pengajian atau universiti. Pembinaan item soal selidik dibuat merangkumi tiga bahagian, iaitu bahagian A (demografi dan latar belakang responden seperti umur, jantina dan etnik), bahagian B (amalan kesantunan berbahasa ketika berkomunikasi dalam konteks formal dan tidak formal), dan bahagian C (kesan amalan kesantunan berbahasa terhadap diri pelajar). Borang soal selidik diedar kepada pelajar selepas sesi kuliah subjek teras universiti. Sebelum soal selidik diedarkan, responden diberikan taklimat ringkas untuk mengisi borang soal selidik tersebut. Kadar respons yang diterima adalah sebanyak 100 peratus.

Data kajian dianalisis secara kuantitatif menggunakan perisian SPSS versi 22 dengan memberi fokus kepada statistik deskriptif, iaitu kekerapan, peratusan, min dan sisihan piawai. Selanjutnya, perbincangan analisis dibuat berdasarkan kepada Teori Kesantunan oleh Brown dan Levinson (1987). Teori ini mengemukakan prinsip kesantunan berasaskan dua jenis 'muka', iaitu muka positif dan muka negatif. Muka positif mewakili hasrat seseorang untuk dipandang secara positif oleh orang lain, dan muka negatif pula mewakili hasrat seseorang yang berharap autonomi peribadinya dihargai oleh orang lain. Dengan kata lain, muka negatif adalah keinginan individu untuk merasakan hak, kebebasan dan kuasa autonomi terhadap tindakan atau perlakuannya. Dengan demikian 'muka' secara keseluruhan adalah citra diri seseorang di hadapan khalayak. Muka ialah sesuatu yang harus dipelihara. Muka juga sesuatu yang dapat terancam. Tindak tutur yang mengancam muka seseorang disebut face- threatening act (FTA) manakala tindak tutur yang memelihara muka seseorang disebut face-saving act (FSA). Sehubungan itu, sebarang bentuk dan lakuan bahasa yang mengundang risiko kepada air muka seseorang dianggap mengancam muka (Brown dan Levinson, 1987). Hasil daripada analisis kekerapan, peratusan, min dan sisihan piawai, dan disandarkan kepada Teori Kesantunan dapat digunakan untuk menjawab persoalan yang berkaitan dengan amalan kesantunan remaja dalam konteks komunikasi formal dan tidak formal, membandingkan amalan kesantunan berbahasa yang diamalkan oleh pelajar UUM mengikut jantina dan membincangkan kesan amalan kesantunan terhadap diri pelajar.

\section{DAPATAN KAJIAN DAN PERBINCANGAN}

Sebelum dapatan kajian dibincangkan secara rinci dengan memberi penumpuan kepada objektif kajian, dipaparkan dahulu tentang latar belakang responden yang merangkumi maklumat; i) umur, ii) jantina, iii) bangsa, dan iv) kawasan tempat tinggal responden. 
i) Umur

Dari segi umur, responden yang tertinggi adalah berumur 21 tahun, iaitu sebanyak 27.7\% (347orang). Seterusnya diikuti responden yang berumur 22 tahun, iaitu sebanyak $24.9 \%$ (311-orang). Responden yang berumur 23 tahun pula adalah sebanyak 19.6\% (245-orang) dan selebihnya dapat dirujuk pada Graf Bar 1 yang memerihalkan keseluruhan kategori umur responden yang mengambil bahagian dalam kajian soal selidik.

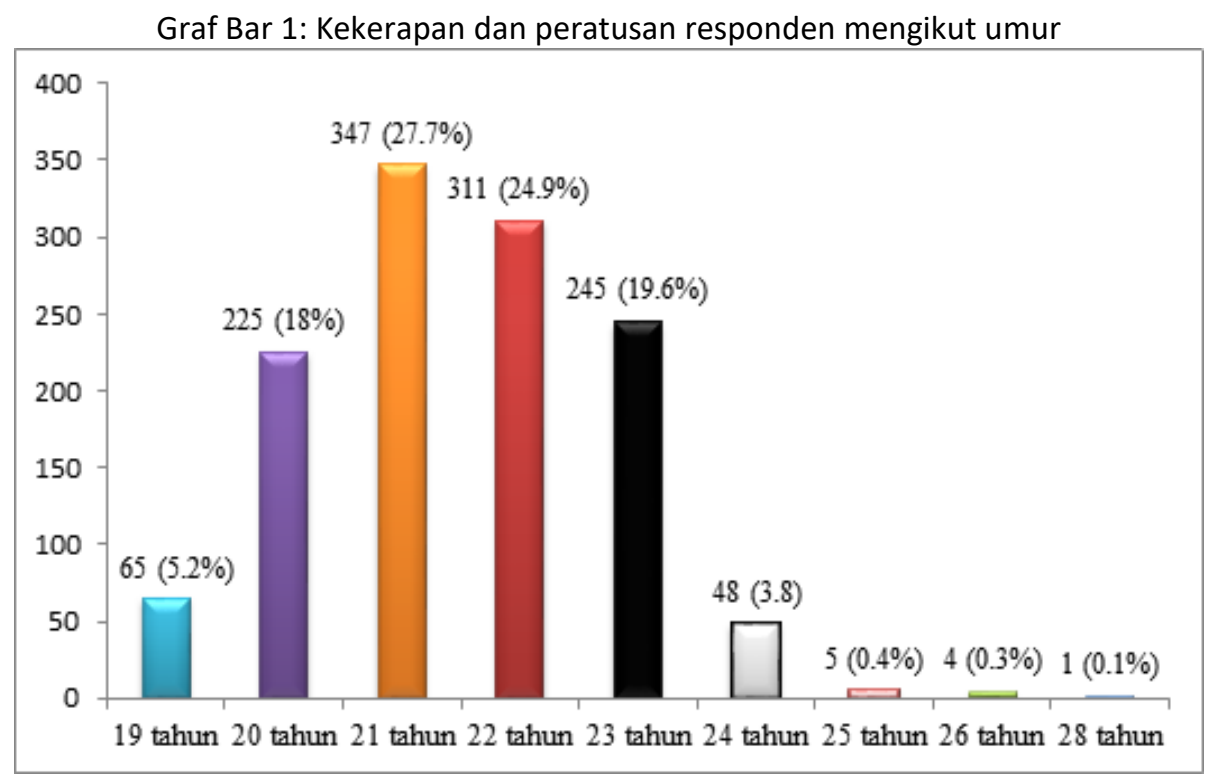

\section{ii) Jantina}

Secara majoriti, remaja perempuan menjadi responden terbesar telah mengambil bahagian dalam kajian ini iaitu sebanyak 69.5\% (869-orang). Selebihnya yakni sebanyak 30.5\% (382-orang) responden mewakili jantina lelaki. Carta Pai 2 memerihalkan peratus dan jumlah keseluruhan responden mengikut jantina.

Carta Pai 2: Bilangan dan peratusan responden mengikut jantina

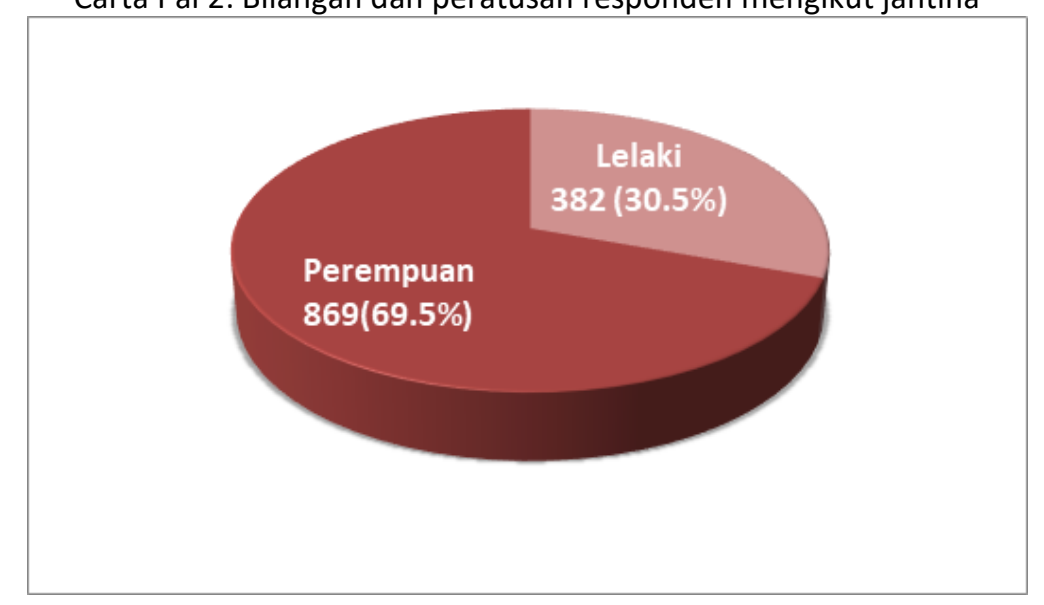


iii) Bangsa

Berkenaan bangsa responden pula, sebanyak 52.7\% (659-orang) responden berbangsa Melayu, diikuti oleh responden berbangsa Cina, iaitu sebanyak 26.3\% (329-orang), seterusnya ialah responden berbangsa India, iaitu sebanyak $17.6 \%$ (220-orang) orang yang menjadi responden. Selebihnya pula ialah responden yang mewakili bangsa peribumi (Siam/lban/Kadazan/lain-lain), iaitu sebanyak 2.2\% (27-orang) dan sebanyak 1.3\% (16-orang) adalah lain-lain bangsa. Graf Bar 3 di bawah memerihalkan secara keseluruhan bagi peratusan bangsa yang menjadi responden.

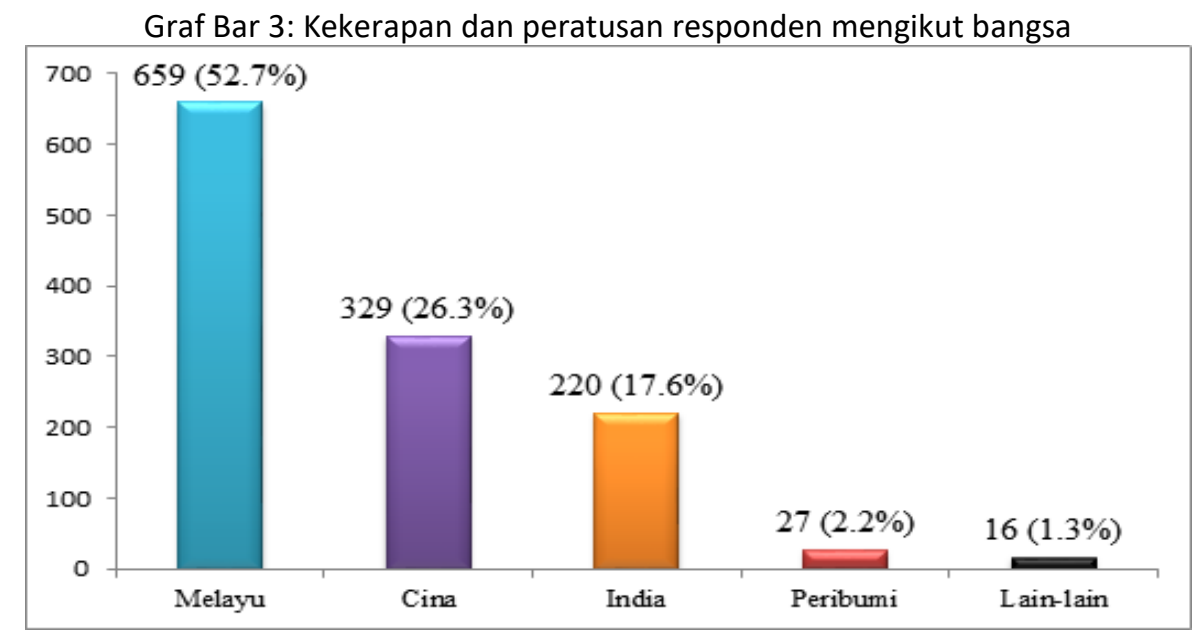

iv) Kawasan Tempat Tinggal

Dalam kajian ini, dua jenis kawasan tempat tinggal responden dinyatakan, iaitu sebanyak $55.4 \%$ (693-orang) responden tinggal di luar bandar dan selebihnya, iaitu sebanyak 44.6\% (558-orang) responden tinggal di bandar. Maklumat berkaitan kawasan tempat tinggal responden dapat dilihat dalam Carta Pai 4 yang berikut.

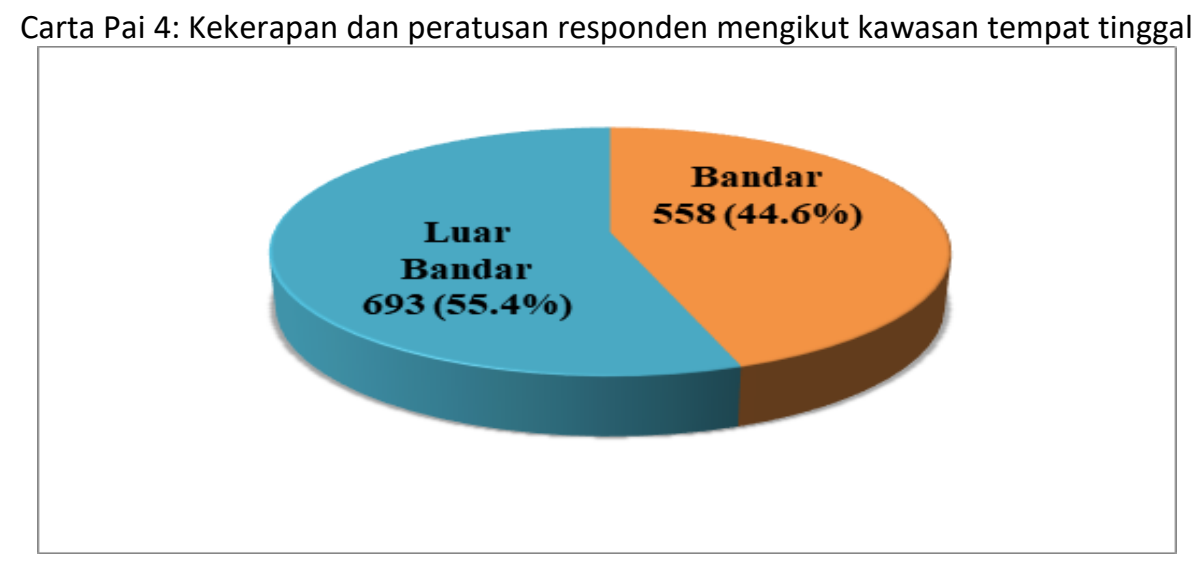

Secara keseluruhan, maklumat yang dipaparkan menjelaskan bahawa kajian ini telah memperoleh maklum balas daripada pelbagai latar belakang atau demografi responden. Hal berkenaan amat penting dalam kajian ini kerana maklum balas yang diperoleh tidak hanya 
mewakili satu-satu latar belakang responden sahaja. Secara tidak langsung dapatan kajian memberikan gambaran yang merangkumi aspek demografi, SES serta latar belakang pengajian yang berbeza terhadap amalan kesantunan dalam kalangan remaja yang menuntut di UUM. Seterusnya, perbincangan dapatan amalan kesantunan berbahasa ini diperhalusi dalam sub bahagian berdasarkan objektif yang dimulai dengan dapatan amalan kesantunan dalam konteks formal dan tidak formal.

\section{a) Amalan Kesantunan Berbahasa Pelajar UUM dalam Konteks Formal dan Tidak Formal} Secara keseluruhannya, amalan kesantunan berbahasa pelajar di UUM sama ada dalam konteks formal mahupun tidak formal menunjukkan sebanyak 93.2\% (1166) orang responden mengamalkan kesantunan berbahasa pada tahap yang tinggi. Hanya $6.8 \%(85)$ orang responden sahaja yang kurang mengamalkan kesantunan berbahasa ketika berkomunikasi, iaitu pada tahap yang sederhana.

Penentuan tahap dalam kajian ini adalah berasaskan Skala Likert lima markat yang dibina dalam borang soal selidik, iaitu rendah, sederhana dan tinggi yang berdasarkan nilai tahap atau range yang ditentukan. Range ditakrifkan sebagai perbezaan antara nilai tertinggi dan terendah dalam borang soal selidik berstruktur yang menggunakan skala likert lima markat, iaitu (1) Sangat Tidak Setuju, (2) Tidak Setuju, (3) Tidak Pasti, (4) Setuju, dan (5) Sangat Setuju. Markat skala likert ini adalah berbentuk ordinal. Tahap persetujuan responden diukur dari skala 1 hingga 5. Data yang diperoleh daripada responden di kod dan dikelaskan semula kepada tiga bahagian, iaitu (1) menunjukkan rendah, (2) menunjukkan sederhana, dan (3) menunjukkan tinggi. Kaedah pengekodan semula bahagian ini bermula daripada nilai terkecil yang diperoleh daripada responden, iaitu nilai 1 dan nilai terbesar adalah 5. Dalam bentuk persamaan: Range $=$ Skor tertinggi - Skor terendah. Julat bagi setiap sela kelas adalah:

$$
5-1 / 3=1.33
$$

Ini bermakna, untuk bahagian ini setiap sela kelas perlu mengandungi 1.33 julat. Jadual 5 menunjukkan skor yang diperoleh dikelaskan mengikut tahap yang telah ditentukan.

\begin{tabular}{lcc} 
& Jadual 5: Pembahagian skor min bagi setiap tahap \\
\hline Skor & Penerangan Tahap \\
\hline 1.00 hingga 2.33 & Rendah \\
2.34 hingga 3.67 & Sederhana \\
3.68 hingga 5.00 & Tinggi \\
\hline
\end{tabular}

Berdasarkan Jadual 5, pembahagian skor min bagi setiap tahap menghasilkan tahap rendah, sederhana dan tinggi. Nilai skor min tahap rendah adalah sebanyak 1.00 hingga 2.33. Nilai skor min tahap sederhana adalah sebanyak 2.34 hingga 3.67, manakala skor 3.68 hingga 5.00 adalah nilai bagi tahap tinggi. Analisis skor min setiap item analisis dipaparkan dalam Jadual 2 yang memerihalkan dapatan kajian bagi setiap item dapatan responden berkenaan amalan kesantunan berbahasa dalam konteks formal dan tidak formal. 
Jadual 6: Kekerapan dan peratusan responden terhadap amalan kesantunan berbahasa pelajar UUM dalam konteks formal dan tidak formal

\begin{tabular}{|c|c|c|c|c|c|c|c|}
\hline \multirow{2}{*}{\multicolumn{2}{|c|}{ Saya mengamalkan kesantunan berbahasa ketika: }} & \multicolumn{2}{|c|}{ Rendah } & \multicolumn{2}{|c|}{ Sederhana } & \multicolumn{2}{|c|}{ Tinggi } \\
\hline & & \multirow{2}{*}{$\begin{array}{l}\mathbf{f} \\
0\end{array}$} & \multirow{2}{*}{$\begin{array}{c}\% \\
0.0\end{array}$} & \multirow{2}{*}{$\begin{array}{c}\mathbf{f} \\
35\end{array}$} & \multirow{2}{*}{$\begin{array}{c}\% \\
2.8\end{array}$} & \multirow{2}{*}{$\begin{array}{c}\mathbf{f} \\
1216\end{array}$} & \multirow{2}{*}{$\begin{array}{c}\% \\
97.2\end{array}$} \\
\hline 1 & $\begin{array}{l}\text { Berkomunikasi dengan pensyarah di dalam } \\
\text { kelas }\end{array}$ & & & & & & \\
\hline 2 & Bertanya soalan kepada pensyarah & 2 & 0.2 & 59 & 4.7 & 1190 & 95.1 \\
\hline 3 & Respon/menjawab soalan pensyarah & 0 & 0.0 & 51 & 4.1 & 1200 & 95.9 \\
\hline 4 & $\begin{array}{l}\text { Bertemu dengan pensyarah di luar kelas } \\
\text { (dalam kawasan universiti) }\end{array}$ & 6 & 0.5 & 80 & 6.4 & 1165 & 93.1 \\
\hline 5 & Berurusan dengan pegawai di kaunter/ pejabat & 3 & 0.2 & 53 & 4.2 & 1195 & 95.5 \\
\hline 6 & Berkomunikasi dengan pelajar senior/junior & 35 & 2.8 & 192 & 15.3 & 1024 & 81.9 \\
\hline 7 & $\begin{array}{l}\text { Berkomunikasi dengan pelajar lain (sama } \\
\text { jantina) }\end{array}$ & 19 & 1.5 & 142 & 11.4 & 1090 & 87.1 \\
\hline 8 & $\begin{array}{l}\text { Berkomunikasi dengan pelajar lain (lain } \\
\text { jantina) }\end{array}$ & 20 & 1.6 & 160 & 12.8 & 1071 & 85.6 \\
\hline 9 & $\begin{array}{l}\text { Berkomunikasi dengan pelajar yang berlainan } \\
\text { bangsa/etnik }\end{array}$ & 6 & 0.5 & 84 & 6.7 & 1161 & 92.8 \\
\hline 10 & Menyertai program pusat pengajian/universiti & 12 & 1.0 & 87 & 1162 & 1152 & 92.1 \\
\hline
\end{tabular}

Berdasarkan 10 item soal selidik dalam jadual 6, item 1 hingga item 5 adalah berkenaan amalan kesantunan berbahasa pelajar UUM dalam konteks formal. Item tersebut adalah amalan kesantunan ketika berkomunikasi dengan pensyarah di dalam kelas, bertanya soalan kepada pensyarah, respon/menjawab soalan pensyarah, bertemu dengan pensyarah di luar kelas (dalam kawasan universiti), dan berurusan dengan pegawai di kaunter atau pejabat. Dalam konteks formal ini, amalan kesantunan berbahasa dalam komunikasi diaplikasikan oleh pelajar dan menunjukkan pada tahap tinggi, iaitu melebihi 90\%. Sebanyak 97.2\% (1216) orang responden mengamalkan kesantunan berbahasa ketika berkomunikasi dengan pensyarah di dalam kelas, 95.1\% (1190) orang responden mengamalkan kesantunan berbahasa ketika bertanya soalan kepada pensyarah, 95.9\% (1200) orang responden mengamalkan kesantunan berbahasa ketika memberi respon/menjawab soalan yang diajukan oleh pensyarah, 93.1\% (1165) orang responden ketika bertemu dengan pensyarah di luar kelas (dalam kawasan universiti), dan 95.5\% (1195) orang responden ketika berurusan dengan pegawai di kaunter/pejabat.

Selain itu, item 6 hingga 10 menguji amalan kesantunan dalam konteks tidak formal. Item yang diuji adalah amalan kesantunan ketika berkomunikasi dengan pelajar senior/junior, berkomunikasi dengan pelajar sama jantina, berkomunikasi dengan pelajar lain berlainan jantina, berkomunikasi dengan pelajar berlainan bangsa/etnik dan ketika menyertai program pusat pengajian/universiti. Dalam konteks yang tidak formal, dapatan kajian menunjukkan bahawa $80 \%$ responden mengamalkan kesantunan berbahasa ketika berkomunikasi pada tahap yang tinggi. Hal ini dapat dilihat sebanyak $81.9 \%$ atau sebanyak 1024 orang responden mengamalkan kesantunan berbahasa ketika berkomunikasi dengan pelajar senior/junior. Sebanyak $87.1 \%$ (1090) mengamalkan kesantunan berbahasa ketika berkomunikasi dengan pelajar lain sama jantina dan $85.6 \%$ (1071) orang responden mengamalkan kesantunan berbahasa ketika 
berkomunikasi dengan pelajar berlainan jantina. Bagi situasi berkomunikasi dengan pelajar berlainan bangsa, sebanyak 92.8\% (1161) orang responden mengamalkan kesantunan berbahasa. Selain itu, sebanyak 92.1\% (1152) orang responden mengamalkan kesantunan berbahasa ketika berkomunikasi dalam menyertai program pusat pengajian/universiti.

Daripada sepuluh item dapatan kajian, kesimpulan berdasarkan orientasi pada konsep 'muka' Brown dan Levinson (1987), menunjukkan bahawa "pelajar yang menjadi responden mengamalkan kesantunan berbahasa dalam konteks yang formal dan tidak formal dengan mengambil kira diri pendengar dan juga kaitannya dengan faktor-faktor lain seperti status sosial, usia, keakraban, tempat atau lokasi dan situasi ketika berkomunikasi. Hal ini demikian kerana pelajar menganggap bahasa yang digunakan oleh mereka itu sesuai mengikut konteks yang melatarinya dan menunjukkan nilai keakraban tanpa menyinggung perasaan seseorang". Dapatan ini selari dengan dapatan kajian Marlyna (2011), yang mendapati "komuniti bahasa Melayu masih berpegang kepada nilai budaya Melayu dan "kesantunan air muka dalam komunikasi antar peribadi yang mendapati bahawa tahap kesantunan berbahasa pelatih PLKN berada pada tahap yang tinggi dengan purata peratus melebihi 90\%" hasil kajian Nor Azuwan et al. (2011).

Selain itu, hasil temu bual yang dijalankan menyatakan bahawa pelajar sememangnya sudah biasa mengamalkan kesantunan berbahasa dalam kehidupan seharian. Sikap dan amalan kesantunan itu bukanlah dibuat-buat untuk mendapatkan perhatian dan pujian daripada orang lain. Mereka hanya akan mengamalkan ketidaksantunan berbahasa sekiranya ada tindak tutur yang mengancam muka face-threatening act (FTA) mereka. Sebarang bentuk dan lakuan bahasa yang mengundang risiko kepada air muka atau dianggap mengancam 'muka' (Brown \& Levinson, 1987) mereka, secara tidak langsung atau pun secara sengaja mereka tidak dapat mempraktikkan amalan kesantunan berbahasa. Sebaliknya mereka akan menggunakan kekerasan dalam komunikasi mereka untuk mempertahankan diri atau membalas sikap dan perbuatan yang tidak santun terhadap mereka lebih-lebih lagi dalam konteks yang tidak formal. Selanjutnya, berdasarkan sepuluh item dapatan soal selidik tentang amalan kesantunan dalam konteks formal dan tidak formal, didapati wujud perbezaan yang signifikan dan tidak signifikan terhadap amalan kesantunan berdasarkan jantina lelaki dan perempuan.

\section{b) Perbezaan Amalan Kesantunan Berdasar Jantina}

Amalan kesantunan berbahasa dalam komunikasi turut dipengaruhi oleh jantina. Jantina ialah pemboleh ubah penting dalam mana-mana kajian bahasa atau komunikasi. Eckert dan McConnell-Ginet (2003) menjelaskan bahawa kajian yang melibatkan jantina merupakan satu penelitian terhadap apa-apa yang dilakukan oleh mereka. Melalui komunikasi bahasa juga, dapat dikenal pasti tingkah laku bergender dalam keadaan tertentu (Schieffelin \& Ochs, 1986). Menurut Johnson (1997), bahasa ialah salah satu daripada sumber yang dirujuk oleh individu atau masyarakat untuk mengetahui peranan jantina dan identiti.

Ujian-t digunakan dalam kajian ini bagi menganalisis satu pemboleh ubah bebas, iaitu jantina dengan dua kumpulan (lelaki dan perempuan) dan satu pemboleh ubah bersandar selanjar (interval), iaitu amalan kesantunan berbahasa dalam komunikasi formal dan tidak formal. 
Jadual 7 menunjukkan keputusan ujian-t amalan kesantunan berbahasa pelajar UUM berdasarkan jantina. Daripada analisis statistik t tersebut, ujian Levene menunjukkan signifikan $(p<.05)$, iaitu terdapat perbezaan yang signifikan tahap amalan kesantunan berbahasa pelajar UUM jantina, $\mathrm{t}(1249)=3.652, \mathrm{p}<.05$. Nilai min tahap amalan kesantunan bagi kedua-dua jantina mencatatkan tahap yang tinggi. Walau bagaimanapun min pelajar perempuan (4.22) lebih tinggi berbanding pelajar lelaki (4.14). Oleh hal yang demikian, hasil daripada kajian tersebut, dapatlah disimpulkan bahawa pelajar perempuan lebih mengamalkan kesantunan berbahasa dalam berkomunikasi sama ada formal atau tidak formal berbanding pelajar lelaki. Dapatan ini mengiakan pandangan Eckert dan McConnel-Ginet (2003) yang menyatakan bahawa cara perempuan bercakap lebih menampakkan unsur penghormatan, teragak-agak dan tidak langsung.

Jadual 7: Keputusan ujian-t amalan kesantunan berdasarkan jantina

\begin{tabular}{lcccccc}
\hline Jantina & N & Min & SP & df & t & Sig. \\
\hline Lelaki & 382 & 4.14 & .396 & 1249 & 3.652 & .000 \\
Perempuan & 869 & 4.22 & .362 & & & \\
\hline
\end{tabular}

${ }^{*} \mathrm{p}<.05$

Secara terperinci, kajian mendapati bahawa daripada sepuluh item yang diuji dalam borang soal selidik, sebanyak tiga item telah mencatatkan perbezaan yang signifikan dari segi amalan kesantunan berbahasa pelajar UUM dalam konteks formal dan tidak formal. Tiga item yang menunjukkan perbezaan yang signifikan itu ialah item 1: "responden mengamalkan kesantunan berbahasa ketika berkomunikasi dengan pensyarah di dalam kelas", item 5: "responden mengamalkan kesantunan berbahasa ketika berurusan dengan pegawai di kaunter/pejabat", dan item 7: "responden mengamalkan kesantunan berbahasa ketika berkomunikasi dengan pelajar lain (sama jantina)". Item 1 mencatatkan nilai t sebanyak -1.134, item 2 sebanyak -2.989 dan sebanyak -3.280 merupakan nilai t bagi item 7. Hal berkenaan dapat diperhalusi dalam Jadual 8 yang berikut.

Jadual 8: Amalan kesantunan berbahasa pelajar UUM yang signifikan mengikut jantina

\begin{tabular}{clccccc}
\hline Item & & Jantina & $\mathrm{N}$ & $\mathrm{Min}$ & Nilai t & Nilai Sig. \\
\hline 1. & Berkomunikasi dengan pensyarah di & $\mathrm{L}$ & 382 & 4.51 & -1.134 & .002 \\
& dalam kelas & $\mathrm{P}$ & 869 & 4.55 & & \\
5. & berurusan dengan pegawai di & $\mathrm{L}$ & 382 & 4.36 & -2.989 & .002 \\
& kaunter/ pejabat & $\mathrm{P}$ & 869 & 4.47 & & .002 \\
& berkomunikasi dengan pelajar lain & $\mathrm{L}$ & 382 & 3.95 & -3.280 \\
& (sama jantina) & $\mathrm{P}$ & 869 & 4.09 & & \\
\hline
\end{tabular}

$\mathrm{P}<0.05$ terdapat perbezaan yang signifikan

Daripada hasil analisis ketiga-tiga item ini, didapati bahawa remaja perempuan lebih menonjolkan amalan kesantunan dan berbudi bahasa sewaktu berkomunikasi dalam konteks formal mahupun tidak formal. Oleh hal yang demikian, dapatlah disimpulkan bahawa terdapat 
perbezaan yang signifikan amalan kesantunan berbahasa dalam kalangan pelajar UUM mengikut jantina lelaki dan perempuan. Amalan kesantunan berbahasa remaja perempuan ini menampakkan bahawa mereka hanya menggunakan unsur yang bersahaja (tidak keterlaluan) dalam ujaran mereka seperti pendapat (Mills, 2003) dan lebih menampakkan identiti dalam mencapai matlamat perbualan mereka (Maltz \& Borker, 1982; Cotes, 1986, 1995), malahan menyalurkan kepada gaya pertuturan tidak langsung (Eckert \& McConnell-Ginet, 2003). Selain itu, amalan kesantunan berbahasa remaja perempuan ini juga menonjolkan kecenderungan mereka untuk menggunakan bahasa yang lebih lembut (Holmes, 1995) selain menggunakan strategi pengurangan risiko untuk mengurangkan ancaman muka seseorang (Zimmerman \& West, 1975; Fishman, 1978, 1980; Tannen, 1984, 1990).

Seterusnya, tujuh item selebihnya dalam dapatan kajian ini mendapati bahawa tidak terdapat perbezaan yang signifikan dari segi amalan kesantunan berbahasa pelajar UUM dalam komunikasi formal mahupun tidak formal antara pelajar lelaki dengan perempuan. Tujuh item yang dimaksudkan adalah item 2: "bertanya soalan kepada pensyarah", item 3: "respon/menjawab soalan pensyarah", item 4: "bertemu dengan pensyarah di luar kelas (dalam kawasan universiti)", item 6: "berkomunikasi dengan pelajar senior/junior", item 8: "berkomunikasi dengan pelajar lain (lain jantina)", item 9 dan item 10: "berkomunikasi dengan pelajar yang berlainan bangsa/etnik" dan "menyertai program pusat pengajian/universiti". Hal ini dapat dirujuk pada Jadual 9 di bawah.

Jadual 9: Amalan Kesantunan Berbahasa Pelajar UUM Yang Tidak Signifikan Mengikut Jantina

\begin{tabular}{|c|c|c|c|c|c|c|}
\hline Item & & Jantina & $\begin{array}{c}N \\
1251 \\
\end{array}$ & Min & Nilai t & Nilai Sig. \\
\hline \multirow[t]{2}{*}{2} & Bertanya soalan kepada pensyarah & $\mathrm{L}$ & 382 & 4.46 & -.415 & .047 \\
\hline & & $P$ & 869 & 4.47 & & \\
\hline \multirow[t]{2}{*}{3} & Respon/menjawab soalan pensyarah & $\mathrm{L}$ & 382 & 4.45 & .033 & .056 \\
\hline & & $P$ & 869 & 4.45 & & \\
\hline \multirow[t]{2}{*}{4} & Bertemu dengan pensyarah di luar kelas & $\mathrm{L}$ & 382 & 4.34 & -1.583 & .130 \\
\hline & (dalam kawasan universiti) & $\mathrm{P}$ & 869 & 4.40 & & \\
\hline \multirow[t]{2}{*}{6} & Berkomunikasi dengan pelajar & $\mathrm{L}$ & 382 & 4.03 & -2.669 & .746 \\
\hline & senior/junior & $P$ & 869 & 4.15 & & \\
\hline \multirow[t]{2}{*}{8} & Berkomunikasi dengan pelajar lain (lain & $\mathrm{L}$ & 382 & 4.03 & -3.709 & .623 \\
\hline & jantina) & $P$ & 869 & 4.18 & & \\
\hline \multirow[t]{2}{*}{9} & Berkomunikasi dengan pelajar yang & $\mathrm{L}$ & 382 & 4.10 & 1.171 & .006 \\
\hline & berlainan bangsa/etnik & $\mathrm{P}$ & 869 & 4.05 & & \\
\hline \multirow[t]{2}{*}{10} & Menyertai program pusat & $\mathrm{L}$ & 382 & 4.18 & -3.138 & .945 \\
\hline & pengajian/universiti & $\mathrm{P}$ & 869 & 4.29 & & \\
\hline
\end{tabular}

$\mathrm{P}<0.05$ terdapat perbezaan yang signifikan

Jadual 9 tersebut menunjukkan bahawa dapatan tujuh item soal selidik amalan kesantunan berbahasa yang tidak signifikan berdasarkan jantina. Maksud tidak signifikan antara gender ini adalah tidak terdapat perbezaan amalan kesantunan berbahasa dalam komunikasi antara pelajar lelaki dan perempuan terhadap tujuh item tersebut dalam komunikasi seharian mereka, sama ada dalam konteks formal mahupun tidak formal. Hal ini membayangkan bahawa orientasi pada konsep 'muka' yang dibawa oleh Brown dan Levinson (1987) diaplikasi oleh pelajar 
yang menjadi responden kebanyakannya mempraktikkan amalan kesantunan berbahasa ketika berkomunikasi. Oleh hal yang demikian, dapatlah dikatakan bahawa amalan kesantunan berbahasa dalam kalangan pelajar UUM berupaya memberikan kesan terhadap diri mereka.

\section{c) Kesan Amalan Kesantunan Terhadap Diri Pelajar}

Amalan kesantunan berbahasa ini dapat memberikan kesan positif terhadap diri pelajar. Jadual 6 di bawah memaparkan kesan amalan kesantunan terhadap diri mereka, iaitu sebanyak $94.3 \%$ (1180) orang responden bersetuju bahawa amalan kesantunan berupaya memberikan kesan kepada mereka, iaitu mereka akan "menjadi ceria dan gembira dengan suasana kampus", 93.2\% (1166) orang responden "menjadi lebih bersemangat untuk belajar". Tambahan pula, apabila seseorang itu sentiasa mengamalkan kesantunan ketika berkomunikasi, sebanyak 94.1\% (1177) orang pelajar akan berusaha "menjadi seseorang yang sentiasa peka dan menjaga air muka orang lain" dan akan selalu "mengajak/menasihati orang lain untuk lebih santun" (94.2\%). Seterusnya, kesan amalan kesantunan ini dapat "membentuk diri pelajar/warga kampus seterusnya komuniti masyarakat yang santun dan berbudi bahasa" (95.5\%). Hal ini dapat dirujuk berdasarkan Jadual 10 di bawah.

Jadual 10: Kekerapan dan peratusan kesan amalan kesantunan terhadap diri pelajar

\begin{tabular}{|c|c|c|c|c|c|c|c|}
\hline \multirow{2}{*}{\multicolumn{2}{|c|}{ Kesan terhadap diri pelajar }} & \multicolumn{2}{|c|}{ Rendah } & \multicolumn{2}{|c|}{ Sederhana } & \multicolumn{2}{|c|}{ Tinggi } \\
\hline & & \multirow{2}{*}{$\frac{f}{14}$} & \multirow{2}{*}{$\begin{array}{c}\% \\
1.1\end{array}$} & \multirow{2}{*}{$\frac{\mathbf{f}}{57}$} & \multirow{2}{*}{$\begin{array}{c}\% \\
4.6\end{array}$} & \multirow{2}{*}{$\frac{\mathbf{f}}{1180}$} & \multirow{2}{*}{$\begin{array}{c}\% \\
94.3\end{array}$} \\
\hline 1 & $\begin{array}{l}\text { Menjadi seorang yang ceria dan gembira dengan } \\
\text { suasana kampus }\end{array}$ & & & & & & \\
\hline 2 & Lebih bersemangat untuk belajar & 17 & 1.4 & 68 & 5.4 & 1166 & 93.2 \\
\hline 3 & $\begin{array}{l}\text { Menjadi seorang yang sentiasa peka dan } \\
\text { menjaga air muka orang lain }\end{array}$ & 9 & 0.7 & 65 & 5.2 & 1177 & 94.1 \\
\hline 4 & $\begin{array}{l}\text { Mengajak/menasihati orang lain untuk lebih } \\
\text { santun }\end{array}$ & 10 & 0.8 & 62 & 5.0 & 1179 & 94.2 \\
\hline 5 & $\begin{array}{l}\text { Dapat membentuk diri pelajar/warga kampus } \\
\text { seterusnya komuniti masyarakat yang santun } \\
\text { dan berbudi bahasa }\end{array}$ & 7 & 0.6 & 49 & 3.9 & 1195 & 95.5 \\
\hline
\end{tabular}

\section{KESIMPULAN}

Amalan kesantunan berbahasa antara penutur mahupun pendengar merupakan suatu kesepakatan atau prinsip abstrak yang harus dipatuhi dalam sesebuah komunikasi. Pada hakikatnya, elemen kesantunan berbahasa sewaktu berkomunikasi ialah teknik atau pun upaya untuk mengurangkan dampak negatif pada khalayak. Selain itu, ianya menjadi hak dan keperluan dalam hubungan sosial sewaktu berkomunikasi lebih-lebih lagi dalam kalangan pelajar yang berbilang bangsa, budaya dan agama di universiti. Berdasarkan sepuluh item soal selidik tentang amalan kesantunan berbahasa pelajar UUM, didapati bahawa "lebih daripada 90\% pelajar mengamalkan kesantunan berbahasa dalam konteks formal dan tidak formal". Dalam konteks tidak formal atau semi formal, pelajar tetap mengamalkan kesantunan berbahasa walaupun hanya segelintir pelajar sahaja, iaitu "6.8\% (85) orang yang kurang mengamalkan kesantunan berbahasa dalam komunikasi". Hakikatnya, amalan kesantunan berbahasa dalam komunikasi 
sesama pelajar UUM telah berupaya memberikan kesan yang positif kepada mereka dalam suasana kehidupan di kampus sama ada dalam konteks formal mahu pun tidak formal. Oleh hal yang demikian, amalan kesantunan berbahasa ketika berkomunikasi perlulah dijadikan norma budaya dalam pertuturan sama ada dari pihak penutur mahu pun pendengar. Dalam konteks kajian ini, dapatlah disimpulkan bahawa amalan kesantunan berbahasa dalam kalangan remaja berada pada tahap tinggi, iaitu melebihi $90 \%$ remaja mengamalkan kesantunan sama ada dalam konteks formal mahu pun tidak formal. Isu tahap kesantunan generasi muda yang kian merosot dan membimbangkan seperti yang dinyatakan sebelum ini bukanlah menggambarkan amalan kesantunan berbahasa dalam kalangan remaja di Malaysia secara keseluruhannya. Isu ini hanya berlaku dalam segelintir remaja yang berkemungkinan terpinggir dalam pelajaran, remaja yang mengalami masalah kemurungan dan pelbagai faktor lain. Amalan kesopanan dan kesusilaan oleh semua rakyat Malaysia seperti yang termaktub dalam "Prinsip Rukun Negara" perlulah disemarakkan dalam semua konteks lapangan agar ianya menjadi gambaran nilai budaya bangsa di Malaysia.

\section{PENGHARGAAN}

Artikel ini merupakan sebahagian dari hasil penyelidikan dana Jabatan Pengajian Tinggi di bawah geran RAGS (RAGS/1/2014/SSI01/UUM//2)

\section{BIODATA}

Ahmad Fuad Mat Hassan ialah Pensyarah Kanan di Pusat Pengajian Bahasa, Tamadun dan Falsafah, Universiti Utara Malaysia, Sintok Kedah. Giat menjalankan penyelidikan dan penulisan dalam bidang Sosiolinguistik dan Pragmatik, bahasa dan budaya Melayu. E-mel: afuad@uum.edu.my

Khairul Faiz Alimi ialah Pensyarah Kanan di Pusat Pengajian Bahasa, Tamadun dan Falsafah, Universiti Utara Malaysia, Sintok Kedah. Giat menjalankan kajian penyelidikan dan penerbitan dalam bidang Fonetik dan Fonologi Melayu. E-mel: kfalimi@uum.edu.my

Hishamudin Isam ialah Pensyarah Kanan di Pusat Pengajian Bahasa, Tamadun dan Falsafah, Universiti Utara Malaysia, Sintok Kedah. Giat menjalankan penyelidikan dan penerbitan dalam bidang Semantik dan Pragmatik, Linguistik Kognitif dan Budaya Melayu. E-Mel: din@uum.edu.my

Mashetoh Abd. Mutalib ialah Pensyarah Kanan di Pusat Pengajian Bahasa, Tamadun dan Falsafah, Universiti Utara Malaysia, Sintok Kedah. Giat menjalankan penyelidikan dan penerbitan dalam bidang Sosiolinguistik khususnya berkaitan Dialektologi (rural dan bandar) dan budaya Melayu. E-mel: mashetoh@uum.edu.my 


\section{RUJUKAN}

Arina Johari, \& Indirawati Zahid. (2016). Manifestasi kesantunan Melayu dalam ujaran memberi dan meminta nasihat. GEMA Online Journal of Language Studies, 16(2), 73-94.

Asmah Haji Omar. (2003). Language and culture in the civilization process. Jurnal Peradaban Melayu, 1, 83-106.

Asmah Haji Omar. (2015). Ensiklopedia bahasa Melayu. Kuala Lumpur: Dewan Bahasa dan Pustaka.

Brown, P., \& Levinson, S. C. (1978). Politeness. Universals in Language usage: Politeness Phenomenon. In E. N. Goody (Ed.), Questions and politeness: Strategies in sosial interaction. New York: Cambridge University Press.

Brown, P., \& Levinson, S. C. (1987). Politeness some universals in language usage. New York: Cambridge University Press.

Creswell, J. W. (2008). Research design. United Kingdom: SAGE Publications Ltd.

Eckert, P., \& McConnell-Ginet, S. (2003). Language and gender. United Kingdom: Cambridge University Press.

Firdaus Abdullah. (2011, 7 Julai). Bahasa Melayu golongan muda merosot. Utusan Malaysia, hlm. 17.

Holmes, J., \& Stubbe, M. (2003). Power and politeness in the workplace. Pearson.

Holmes, J. (1995). Women, men and politeness. London: Longman Publisher.

Ibrahim. (2019). Konteks budaya dalam komunikasi antarabudaya (Kes pelajar IAIN Pontianak, Indonesia). Jurnal Komunikasi: Malaysian Journal of Communication, 35(2), 227-246.

Kalthum Ibrahim, \& Nur Faezah Kamaruzaman. (2017). Kesantunan bahasa dalam rancangan bual bicara Meletop: Satu kajian sosiolinguistik. Jurnal Linguistik, 21(2), 060-068.

Lakoff, R. T., \& Bucholtz, M. (2004). Language and women's place: Text and commentaries. NY: Harper Colophom.

Lakoff, R. T. (1975). Language and women's place. NY: Harper Colophom.

Lakoff, R. (1989). The limits of politeness. Multilingua, 8, 101-129.

Maltz, D. N., \& Borker, R A. (1982). A cultural approach to male-female miscommunication. In Coates, J. (Ed.), The matrix of language: Contemporary language anthropology (pp. 417434). Cambridge: Cambridge University Press.

Marlyna Maros. (2011). Strategi kesantunan Melayu dalam membuat teguran. e-Utama: Jurnal Elektronik Jabatan Bahasa \& Kebudayaan Melayu, 3, 7-20.

Maslida Yusof. (2018). Trend ganti nama diri bahasa Melayu dalam konteks media sosial. Jurnal Komunikasi: Malaysian Journal of Communication, 4(2), 36-50.

Mills, S. (2003). Gender and politeness. Cambridge: Cambridge University Press.

Mills, S. (2004). Class, gender and politeness. Multilingua, 23(1/2), 171-191.

Mustafa Haji Daud. (1995). Budi bahasa dalam tamadun Islam. Kuala Lumpur: Dewan Bahasa dan Pustaka.

Nor Azuwan Yaakob, Norazlina Mohd Kiram, Kamariah Kamaruddin, \& Zaitul Azma Zainon Hamzah. (2011). Kesantunan berbahasa dalam aktiviti Program Latihan Khidmat Negara (PLKN). Journal of Human Capital Development, 4(1), 53-77. 
Norhana Bakhary, Zaitul Azma Zainon Hamzah, Mohd Zariat Abd Rani, \& Omrah Hussin. (2010). Kesantunan bahasa dalam kata perbilangan adat perpatih: Satu tinjauan awal. Jurnal Linguistik, 11(Disember), 1-20.

Nur Damia Husna Nor Sad, \& Zulkefli Haji Aini. (2015). Kesantunan berbahasa dalam komunikasi dakwah. Kertas kerja yang dibentangkan dalam Persidangan Kebangsaan Komunikasi, Kemanusiaan, Sains Sosial dan Sains, 21 Oktober 2015, Universiti Sains Islam Malaysia.

Rais Yatim. (2011, Julai 1). Tahap kesopanan generasi muda kini semakin menurun berbanding dengan belia di negara luar. Utusan Malaysia.

Sa'adiah Ma'alip. (2015). Pemilihan bahasa dalam komunikasi di laman sosial. Jurnal Komunikasi: Malaysian Journal of Communication, 31(2), 231-246.

Schieffelin, B., \& Ochs, E. (1986.) Language socialization across cultures. Cambridge: Cambridge University Press.

Zaitul Azma Zainon Hamzah. (2009). Parameter kesopanan dalam kalangan kanak-kanak dan remaja: Analisis pragmatik. Laporan penyelidikan yang tidak diterbitkan. Serdang: Universiti Putra Malaysia.

Zimmerman, D., \& West, C. (1975). Sex roles, interruptions and silences in conversation. In B. Thorne, \& N. Henley (Eds.), Language and sex: Difference and dominance (pp. 105-129). Rowley, Massachusetts: Newbury House.

Zuraini Ramli, Husna Faredza Mohamed Redzwan, Dahlia Janan, \& Khairul Azam Bahari. (2009). Amalan kesantunan berbahasa sebagai cerminan santun budaya dalam memartabatkan bahasa Melayu. Retrieved from researchgate.net/publication/336375332

Zulkifley Hamid, Naidatul Zamrizam Abu, \& Asyraf Zulkifley (2015). Strategi komunikasi dalam kalangan murid pelbagai etnik. Jurnal Komunikasi: Malaysian Journal of Communication, 31(1), 171-186. 